DOI: $10.2478 / \mathrm{v} 10025-008-0004-3$

JOURNAL OF WATER

AND LAND DEVELOPMENT

J. Water Land Dev. No. 11, 2007: 45-58

\title{
Water management measures analysed for Dutch basins to reduce flooding
}

\author{
Erik P. QUERNER
}

Alterra, Centre for Water and Climate, P.O. Box 47, 6700 AC Wageningen, The Netherlands; email: erik.querner@wur.nl

\begin{abstract}
Flooding in the northern part of The Netherlands has caused serious economic threats to densely populated areas. Therefore a project has been carried out in a pilot area to assess the retention of water in two river basins as a way to reduce flooding. The physically-based groundwater and surface water model SIMGRO was used to model the hydrology of the basins. The model was calibrated using discharges and groundwater levels. Scenarios of measures to assess the possibility of retaining water in the basin were then defined and tested. The first measure was the retention of higher discharges using culverts or gates in the upstream part of the basin. The second measure was to make the streams shallower and thereby, increase flood plain storage. The last measure was flood water storage in a designated area in the downstream part of one basin. The analysis indicates that holding water in the upstream parts of the basins proved to be feasible and can result in significant reductions of peak flows.
\end{abstract}

Key words: drainage basin, evapotranspiration, groundwater, modelling, rainfall, river basin, scenario, surface water

\section{INTRODUCTION}

Worldwide there has been an increase in the number of floods and droughts that effect large number of people and cause enormous economic losses. In the period 1990 to 1998 the number of recorded flood disasters in Europe was higher than in the previous three and a half decades (Sustainable..., 2001). Because of this situation it is clear that measures have to be taken to reduce the impact of these extreme hydrological events.

The Netherlands was originally a marshy delta formed by the rivers Rhine and Meuse. A rise in sea level, coupled with subsidence of the ground level means that more than half the country is now below sea level (the low-lying part); the remainder is only slightly above sea level. Throughout the country the water table is shallow (between 0.3 and $2.5 \mathrm{~m}$ below the soil surface) and a dense network of engi- 
neered watercourses is needed to drain the land. Because of the improved drainage conditions, water can flow quickly from the upper part of a basin. During recent extreme rainfall events in the northern part of The Netherlands the rapid flow from the upper parts of the basin caused flooding of some polders and resulted in a serious threat of flooding of densely populated areas.

After a Dutch national study "Water Management in the 21st Century" a policy was adopted to retain more water in the upper part of river basins in order to avoid flooding in the downstream parts. As part of this national study, measures designed to retain water were analysed in six basins across The Netherlands (QUERNER, 2002). Understanding the hydrology in these basins provided a proper basis for decision making on feasible measures. Analysis of the complex, and engineered Dutch river systems requires the use of a combined groundwater and surface water model to predict the effect of measures on a regional scale. In this study the SIMGRO model was used. This model simulates the flow of water in the saturated zone, the unsaturated zone and the surface water. The model is physicallybased and therefore suitable for use in situations with changing hydrological conditions.

In order to give solutions for an integrated river basin management plan for the northern part of the Netherlands, one of the problems to solve is how to reduce the peak discharge. The question is how to retain more water in a river basin. To analyse such situations and possible mitigation measures, tools were used to evaluate them in terms of eco-hydrological impact and the effect on agriculture. In this paper we report on a project carried out to assess the possible retention of water in the upper and lower part of two river basins. First a very brief description of the SIMGRO model is given, followed by the schematisation of the study area, the scenarios and the results.

\section{SIMGRO MODEL}

SIMGRO (SIMulation of GROundwater and surface water levels) is a distributed physically-based model that simulates regional transient saturated groundwater flow, unsaturated flow, actual evapotranspiration, sprinkler irrigation, streamflow, groundwater and surface water levels as a response to rainfall, reference evapotranspiration, and groundwater abstraction. To model regional groundwater flow, as in SIMGRO, the system has to be schematised geographically, both horizontally and vertically. The horizontal schematisation allows input of different land uses and soils per subregion, in order to model spatial differences in evapotranspiration and moisture content in the unsaturated zone. For the saturated zone various subsurface layers are considered (Fig. 1). For a comprehensive description of SIMGROW, including all the model parameters readers are referred to van WALSUM et al. (2004) or QUERNER (1997). 


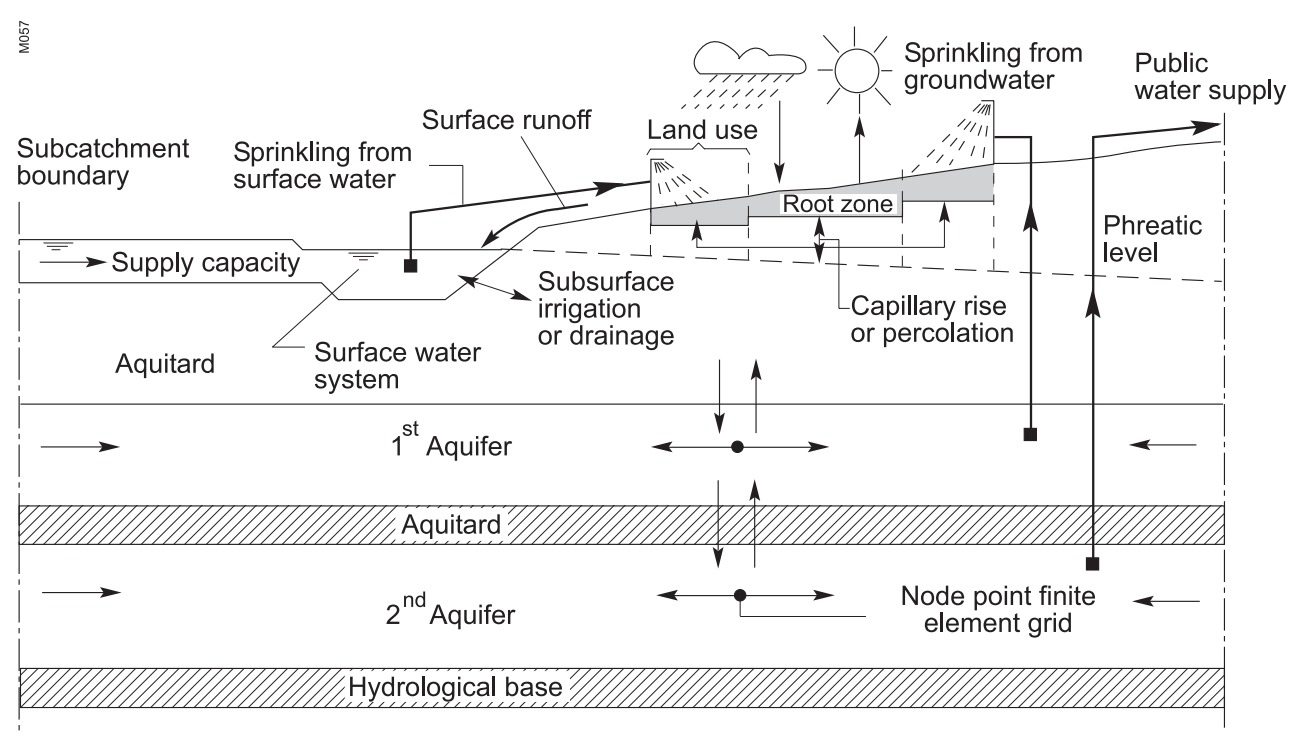

Fig. 1. Schematisation of water flows in the SIMGRO model

\section{GROUNDWATER FLOW}

In SIMGRO the finite element procedure is applied to approach the flow equation which describes transient groundwater flow in the saturated zone. A transmissivity is allocated to each nodal point to account for the regional hydrogeology. A number of nodal points makes up a subcatchment as shown in Figure 1. The unsaturated zone is represented by means of two reservoirs, one for the root zone and one for the underlying soil (Fig. 1). The calculation procedure is based on a pseudo-steady state approach, using generally time steps of one day. If the equilibrium moisture storage for the root zone is exceeded, the excess water will percolate towards the saturated zone. If the moisture storage is less than the equilibrium moisture storage, then water will flow upwards from the saturated zone (capillary rise). The height of the phreatic surface is calculated from the water balance of the subsoil below the root zone, using a storage coefficient. The equilibrium moisture storage, capillary rise and storage coefficient are required as input data and are given for different depths to the groundwater.

Evapotranspiration is a function of the crop and moisture content in the root zone. The measured values for net precipitation, potential evapotranspiration for a reference crop (grass) and woodland are input data for the model. The potential evapotranspiration for other crops or vegetation types are derived in the model from the values for the reference crop by converting with known crop factors. The paved part of the urban area is assumed to have no evaporation, while the unpaved part is considered as grass. 
SURFACE WATER FLOW AND DRAINAGE

The surface water system in the Netherlands is often a dense network of watercourses. It is not feasible to explicitly account for all these watercourses in a regional simulation model, yet the water levels in the smaller watercourses are important for estimating the amount of drainage or subsurface irrigation, and the water flow in the major watercourses is important for the flow routing. The solution is to model the surface water system as a network of reservoirs. The inflow of one reservoir may be the discharge of the various watercourses and ditches, runoff and water from a sewage treatment plant. The outflow from one reservoir is the inflow to the next reservoir. The water level depends on surface water storage, on reservoir inflow and discharge. For each reservoir, input data are required on a 'stage versus storage' relation and a 'stage versus discharge' relation.

Watercourses are important for the interaction between surface water and groundwater. In the model four different categories of drainage ditches (related to its size) are used to simulate the interaction between surface water and groundwater. This interaction is calculated for each drainage subsystem using a drainage resistance and the difference in level between groundwater and surface water.

\section{URBAN AREA}

Urban area is represented in the SIMGRO model as a particular land use type, which is divided into impermeable surfaces (houses and paved areas) and the remaining area where rainwater can infiltrate. The storm water from all impermeable surfaces is collected in a combined storm water and sewage system. The sewer system is represented in the model as a reservoir with a particular storage capacity. Inflow into the reservoir comprises sewage water and storm water, outflow is effluent from the sewage treatment plant which, at its maximum, is equal to the pump capacity of the treatment plant. When the maximum storage of the sewers is exceeded, the excess water flows as an emergency overflow towards the surface water system.

\section{LINKAGE OF GROUNDWATER-SURFACE WATER MODULES}

As the groundwater part reacts much more slowly to changes than the surface water part, both parts have their own time step. The result is that the surface water module performs several time steps during one time step of the groundwater module. The groundwater level is assumed to remain constant during that time and the flow between groundwater and surface water is accumulated using the updated sur- 
face water level. The next time the groundwater module is called up the accumulated drainage or subsurface irrigation is used to calculate a new groundwater level.

\section{GIS INTERFACE ALTERRAQUA}

The SIMGRO model is used within the GIS environment Arcview. It gives the possibility of using digital data, such as a soil map, land use, watercourses, etc., to serve as input data for the model and to show results. It is also a tool for analysis and discussion, because interactively data and results can be presented.

\section{STUDY AREA AND MODEL SCHEMATISATION}

The modelling area covers $1200 \mathrm{~km}^{2}$ and is located in the northern part of the Netherlands (Fig. 1). The area of main interest is approximately $750 \mathrm{~km}^{2}$ and covers the basins of the river Drentsche Aa and Peizerdiep. The ground surface slopes from about $24 \mathrm{~m}+\mathrm{MSL}$ in the south to about $-1 \mathrm{~m}$ in the north. The area consists of sandy soils in the upper parts with clay and peat in the stream valleys and the lower part. Land use is predominantly agricultural and forest. About $42 \%$ is in pasture, $24 \%$ is arable land, $18 \%$ is woodland, $11 \%$ residential and $5 \%$ is other. For the meteorological input data five stations spread over the area were used (QUERNER et al., 2005).

For the SIMGRO model the groundwater system needs to be schematized by means of a finite element network. The network, comprising 49050 nodes, is spaced at about $200 \mathrm{~m}$ in the interest area, but in the stream valleys it is spaced at $75 \mathrm{~m}$. For the modelling of the surface water the basin is subdivided in 5625 subbasins. The difference in height of about $25 \mathrm{~m}$ means that 570 weirs were constructed in the past to control the water level and flow. Most of the weirs are adjustable, so that the target water level in summer can be raised. In the lower part, the polders with a water level near or below sea level, there are 58 pumping stations and 41 inverted siphons.

The geology of the area is quite complex, due to influences from the Pleistocene period, permafrost, tectonic movements, and influences from wind and water. A major influence on the groundwater flow patterns is the resistant impermeable layers formed by boulder clay that cause large areas with perched water tables. The groundwater system in the model is build up of four aquifers that are interlaid with three less permeable layers. The second layer consists of the boulder clay. The interaction between groundwater and surface water is characterized by a drainage resistance. This resistance is derived from hydrological parameters and the spacing of the water courses. 
PERCHED WATER TABLES

The initial SIMGRO model was not able to simulate the perched water tables caused by the boulder clay (model layer 2). In large areas this resulted in phreatic groundwater levels that were 1-3 $\mathrm{m}$ too low. Therefore the model was improved that, on the basis of the hydraulic head below and above the boulder clay, the vertical resistance is adjusted to simulate the flux through this clay layer correctly. Also the storage coefficient above and below the clay layer was changed during the calculations depending on the presence of the perched water table. After the model was improved, calculated phreatic levels were close to the measured ones (see next section).

\section{RESULTS OF SIMGRO MODELLING}

\section{PRESENT SITUATION}

Simulations were carried out for a period of 10 years (1989-1999). The results were compared with measured river discharges (nine locations) and groundwater levels (about 800 piezometers). For three main gauging stations, as shown in Fig. 2 , Table 1 gives the measured and calculated discharges. The discharges are given for a recurrence interval of once in five years to a recurrence interval of 15 times per year (denoted as $15 \mathrm{x}$ per year). The last column in Table 1 gives $Q 95$, the flow occurring less than $5 \%$ of the time. For the Drentsche Aa the calculated discharge is a bit higher than measured (about $8-20 \%$ ). For the other two streams the differences are smaller, in the order of $2-14 \%$. When comparing hydraulic heads, for more than half the total number of piezometers, the difference in measured and calculated head is less than $0.25 \mathrm{~m}$. Comparing only the phreatic levels: for the 332 phreatic piezometers there are 239 with a difference less than $0.5 \mathrm{~m}$ and 145 with a difference less than $0.25 \mathrm{~m}$. These differences between measured and calculated results were regarded as small, so it was concluded that the final model can be used to analyse possible measures to hold water in the upstream part of the basin.

\section{MITIGATION MEASURES AND THE IMPACT}

Mitigation measures were defined that would reduce the peak discharges to acceptable volumes. In this research the following measures were analysed:

1. Restrict peak discharges

Peak flows can be restricted by installing sluice gates or culverts of such a dimension that only the higher peaks are reduced. In the simulations, the opening 


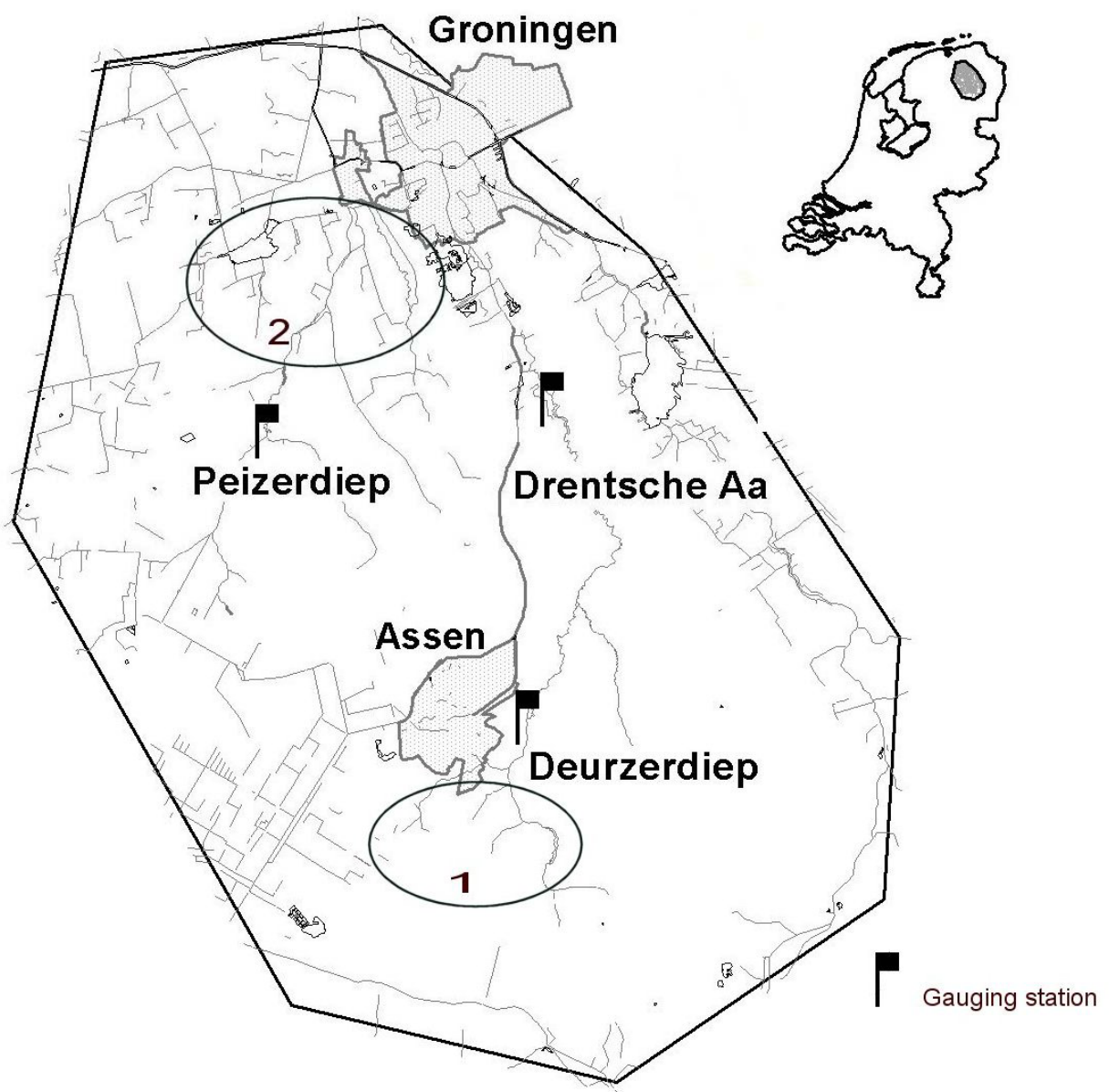

Fig. 2. Location of the modelling area and the main water courses in the northern part of The Netherlands (RAKHORST, 2005). In region 1 measures are taken in the upper part of the basin and in region 2 in the lower part

Table 1. Measured and calculated discharges for three gauging stations $\left(\mathrm{m}^{3} \cdot \mathrm{s}^{-1}\right)$ as shown in Fig. 2 (for recurrence intervals see text)

\begin{tabular}{|c|c|c|c|c|c|c|}
\hline \multirow{2}{*}{ Gauging station } & \multirow{2}{*}{$\begin{array}{l}\text { Measured } \\
\text { Calculated }\end{array}$} & \multicolumn{4}{|c|}{ Discharge for the given recurrence interval } & \multirow{2}{*}{$Q 95$} \\
\hline & & 5 year & 1 year & $5 \mathrm{x}$ per year & $15 \mathrm{x}$ per year & \\
\hline \multirow[t]{2}{*}{ Drentsche Aa } & measured & 11.02 & 8.91 & 6.97 & 5.48 & 0.57 \\
\hline & calculated & 13.63 & 11.57 & 7.58 & 6.24 & 0.36 \\
\hline \multirow[t]{2}{*}{ Deurzerdiep } & measured & 14.45 & 11.52 & 6.34 & 4.00 & 0.27 \\
\hline & calculated & 14.05 & 11.59 & 6.24 & 4.31 & 0.14 \\
\hline \multirow[t]{2}{*}{ Peizerdiep } & measured & 13.64 & 10.45 & 6.57 & 5.01 & 0.08 \\
\hline & calculated & 13.44 & 10.47 & 5.97 & 4.37 & 0.12 \\
\hline
\end{tabular}


of these constructions was such that the flow will be restricted when the flow is higher than occurring once a year.

2. Make the brooks shallower

Reducing the depth of the water course will result in water overtopping the side banks and it will be stored on the flood plain. The storage of the water on the over banks will reduce the flow propagation and thus reducing the peak flow.

3. Flood storage

In a designated area in the lower part of the Peizerdiep under high water conditions flood water is stored.

In Fig. 3 the measures in the upstream part of the Drentse Aa are shown. At eight locations the flow was restricted and over a length of $29 \mathrm{~km}$ the streams were made shallower. In Table 2 the results are given for the two sub basins; it gives the discharge for the reference situation, the two measures and the change in flow. The impact of the first measure (restrict peaks) is more than the second (shallower streams). Limiting the flow by introducing gates or culverts, means a decrease in peak flow in the order of $25-50 \%$. The large variation depends on local conditions and the number of structures in a stream. Limiting the flow has very little influence on

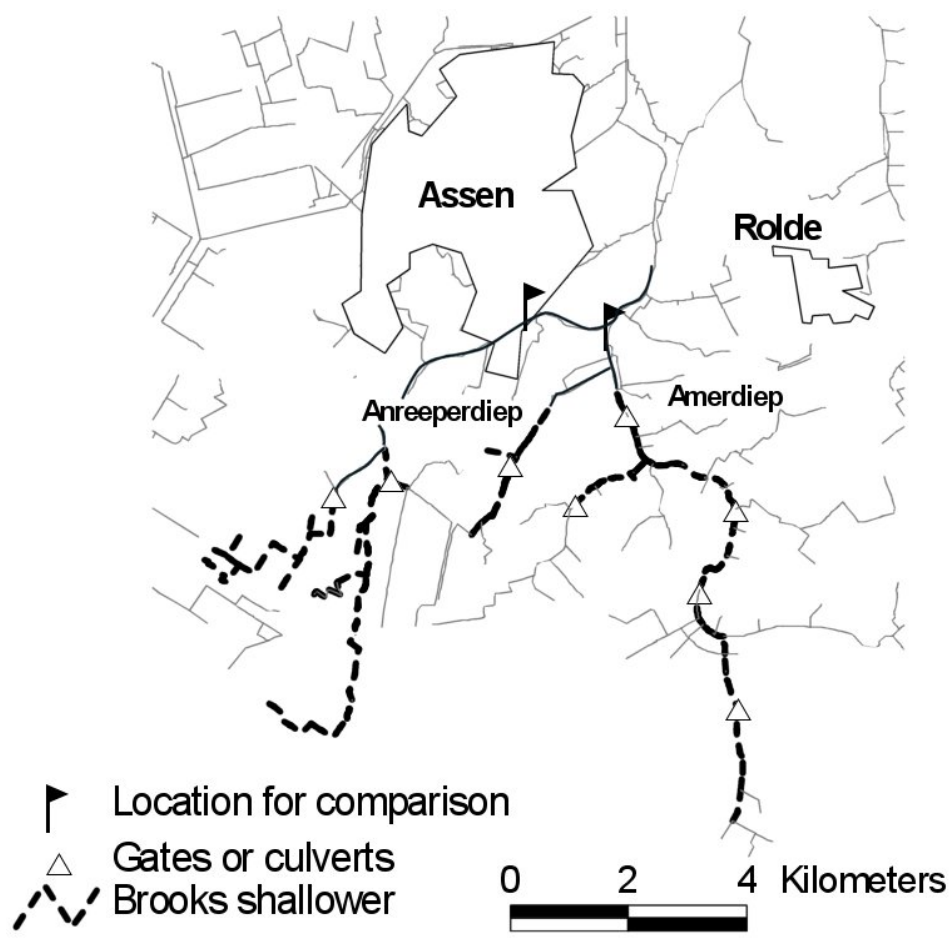

Fig. 3. Location of the mitigation measures carried out in the water courses of the upstream part in the Drentsche Aa. See Fig. 2 for the location in the pilot area 
groundwater levels, because the water flow is obstructed only for a number of days or weeks. Local flooding may occur and thus groundwater levels rise. This small and short rise, often in winter time, has no apparent effect on agriculture or nature.

In the second scenario, when the stream is made shallower, the reduction of peak discharges is in the order of 5-20\% (Table 2). The consequence of this measure is higher water levels in both wet and dry periods. The flow reduction is mainly caused by the water overflowing the river banks and flooding the valley. As a consequence, the groundwater levels adjacent to the stream will be higher. In general the higher levels may have a positive influence on the presence of rare and protected marsh species.

Table 2. Change in discharges $\left(\mathrm{m}^{3} \cdot \mathrm{s}^{-1}\right)$ for $2 \mathrm{sub}$ basins and the two scenarios as shown in Figure 2

\begin{tabular}{l|l|c|c|c|c|c}
\hline \multirow{2}{*}{ Location } & \multirow{2}{*}{ Scenario } & \multicolumn{5}{c}{ Discharge for a given recurrence interval } \\
\cline { 3 - 7 } & & 10 year & 5 year & 1 year & 5 x per year & 15 x per year \\
\hline \multirow{2}{*}{ Amerdiep } & reference & 13.18 & 9.62 & 5.42 & 3.08 & 2.23 \\
& gates & 5.32 & 4.98 & 4.60 & 3.14 & 2.25 \\
& reduction, \% & 60 & 49 & 15 & -2 & -1 \\
& shallower streams & 10.08 & 9.06 & 4.99 & 3.07 & 2.25 \\
& reduction, \% & 24 & 7 & 8 & 0 & -1 \\
Anreeperdiep & reference & 9.12 & 5.81 & 3.38 & 1.94 & 1.47 \\
& gates & 6.97 & 3.74 & 3.02 & 1.97 & 1.48 \\
& reduction, \% & 24 & 36 & 8 & -2 & 0 \\
& shallower streams & 8.47 & 5.53 & 3.44 & 1.93 & 1.43 \\
& reduction, \% & 7 & 4 & 2 & 1 & 1 \\
\hline
\end{tabular}

Flood water storage is considered in the downstream part of the Peizerdiep basin (Fig. 4), where an area is designated for flood water storage (Environmental..., 2006). This area used to be agricultural, but over the last fifty years it was partly changed to a nature area, because of the too wet conditions encountered. The region consists of peat land and subsidence of the soil surface has resulted in a situation that excess water from the area had to be pumped into the river, thus it became a polder. The anticipated flood storage area is around $22.1 \mathrm{~km}^{2}$.

In scenario 3 (flood storage) it has been considered that the water flow in the brooks Peizerdiep and Eelderdiep is flowing thru the flood storage area (Fig. 4). The dikes along both sides of the rivers, separating it from the polders, will be removed. During flooding of this area, water retention will take place and results in lower surface water levels. Before and after the flooding there will be in the polder a strong interaction of the surface water with the groundwater. Such complicated situation made it clear that a model was needed to simulate the effects of measures which integrates groundwater and surface water. 


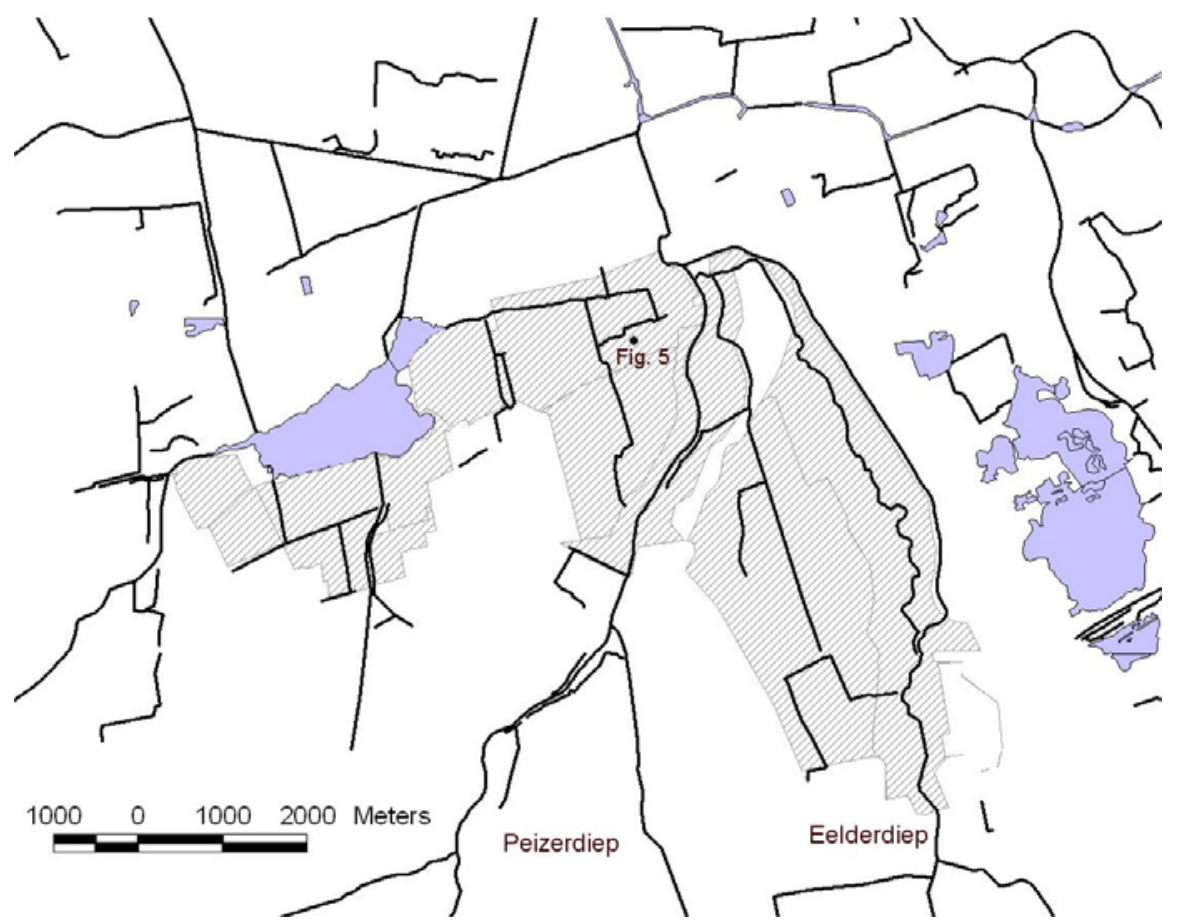

Fig. 4. Location of the flood storage area in the lower part of the Peizerdiep basin. See Fig. 2 for the location in the pilot area

In Fig. 5 the groundwater table is shown for a location in the anticipated flood storage area. In the present situation the target water level for the polder is $-1.30 \mathrm{~m}$ above MSL, but the groundwater table is in summer (dry period) even lower. In winter time the groundwater table is close to ground level, being $-0.9 \mathrm{~m}+\mathrm{MSL}$. In the flood storage scenario the groundwater table remains very close to the ground level, and during wet periods the area is inundated and surface water level and groundwater table are above ground level. Under these situations water is stored in the area, as occurs frequently (Fig. 5). Especially during the months Oct.-Nov. 1998 the inundation is around $0.45 \mathrm{~m}$ deep.

\section{EFFECTIVENESS OF THE THREE MEASURES}

The three measures are compared in terms of the effectiveness to retain water and reduce the peak flow. When the first two measures are introduced the peak flows will be reduced and discharge is spread over a longer time period. As an example, in Fig. 6 the flow situation is given for October and November 1998, a period with extreme rainfall in the northern part of The Netherlands. Figure 6 shows 


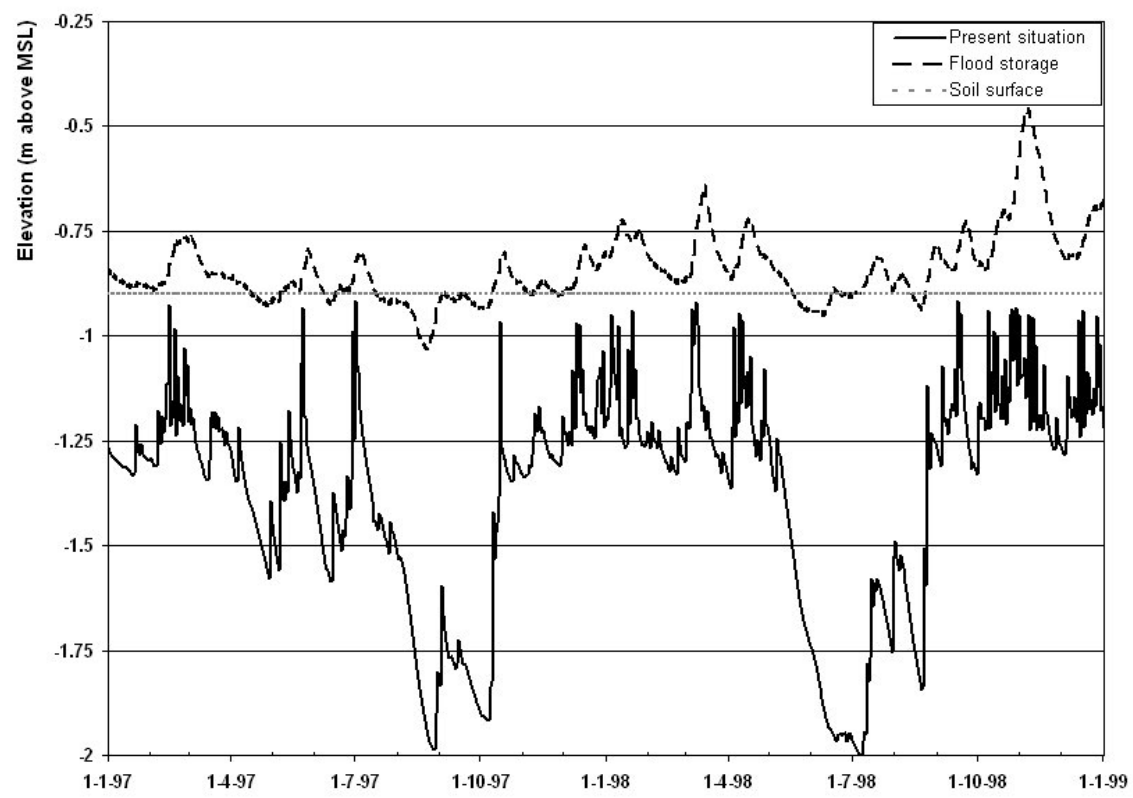

Fig. 5. Groundwater table for the present situation and the flood storage scenario (Fig. 4 shows the location of the node)

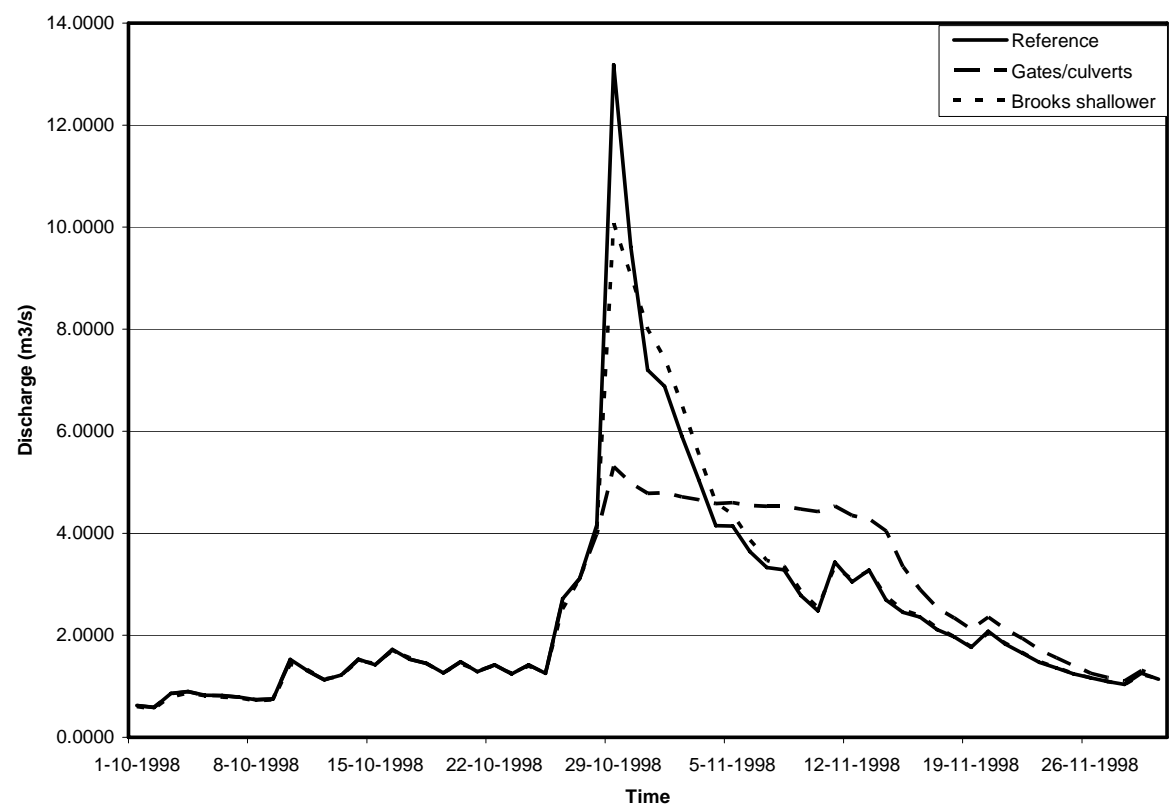

Fig. 6. Discharge for reference situation and two scenarios (restrict flow and brook shallower) for an extreme wet period in 1998 
the calculated discharge for the present situation and the two measures. In the reference situation the duration of the high flow was about one week, but after flow restriction the maximum flow is much smaller as it is spread over a period of 2.5 weeks (Fig. 6). When the streams are made shallower, the maximum peak reduces, but the flood wave reacts very similar as the flood wave in the present situation. When the flow is restricted by gates or culverts in the upstream part of the 3 basins, the storage of water, for the event also shown in Fig. 6, amounts to about $3.2 \mathrm{mln}$ $\mathrm{m}^{3}$. For the scenario when the stream is made shallower the storage of water is much less. For the flood storage scenario in the lower part of the basin the storage is has been estimated around $7.3 \mathrm{mln} \mathrm{m}^{3}$. The difference in storage is about a factor two, but the flood storage scenario is expected to be quite expensive. An area of around $22.1 \mathrm{~km}^{2}$ has to be transformed, such as the relocation of dikes. On the other hand it will become a valuable nature area.

\section{DISCUSSION ON MEASURES FOR EXTREME RAINFALL EVENTS}

In the present situation extreme rainfall extreme events would cause flooding in the low laying areas, which are often densely populated. This situation occurred as well in the autumn of 1998, when in the upper part of the brooks intense rainfall occurred for a number of days. This caused high stream flows and in the lower parts, in the city of Groningen (see Fig. 2), very serious threats of flooding occurred. In this analysis it has been demonstrated that it is feasible to restrict peak flows when they are higher than the discharge occurring once a year. Another approach could be as well to reduce the peak flows which occur once in 10 or 50 years. Take these measures in the upper parts of the basin, thus storing water in extreme events in areas which are not so densely populated. In that way the choice is explicitly accepting local flooding in the upper parts of a catchment where mostly agricultural land is situated, instead of flooding densely populated areas more downstream.

\section{CONCLUSIONS}

The physically-based SIMGRO model was able to simulate stream flow in basins with different land use and climate conditions. The model calibration was limited, but the simulation results show that the model gives satisfactory estimates of the discharges and groundwater levels. The model is therefore an adequate tool to simulate stream flow, and has the potential to assess the impact of measures to reduce flooding.

This study has shown that ecosystems of lowland catchments where the groundwater levels have been lowered by extensive land drainage can be restored 
by restricting the flow from the upper parts. Holding water in the upstream parts of the basins is feasible. The delay of the peak flow is significant. Also the storage of water in designated areas is effective, but is an expensive measure.

For extreme situations, such as occurred in October 1998, it is also possible to use measures to reduce peak flows that have a recurrence of once in 10 or 50 years. In that way the choice is explicitly to accept local flooding in the upper parts of a catchment where mostly agricultural land is situated, instead of flooding high densely populated areas more downstream.

\section{REFERENCES}

1. Environmental assessment study on flood storage (in Dutch), 2006. Report 9R3320, July 2006. Groningen, Royal Haskoning.

2. QUERNER E.P., 1997. Description and application of the combined surface and groundwater model MOGROW. J. Hydrol., 192: 158-188.

3. QUERNER E.P., 2002. Analysis of basin response resulting from climate change and mitigation measures. In: FRIEND 2002, Bridging the gaps between research and practice. Ed. H. van Lanen, S. Demuth). 4th Int. Conf. Friend, Cape Town, South Africa, March 2002. IAHS Publ. 274: 77-84.

4. Querner E.P., Rakhorst M., Hermans A.G.M., Hoegen S., 2005. Exploring the possibilities to retain water on the Drents Plateau; Pilot in Northwest Drenthe (in Dutch). Alterra report 1240. Wageningen, Alterra.

5. RAKHORST M., 2005. Reduction in peak discharges for the Brooks in Northwest Drenthe; estimated with the SIMGRO model (in Dutch). MSc thesis. Wageningen University.

6. Sustainable water use in Europe. Part 3. Extreme hydrological events: floods and droughts, 2001. Environmental issue report 21. Copenhagen, European Environment Agency (EEA).

7. Van Walsum P.E.V., Veldhuizen A.A., Van Bakel P.J.T., Van Der Bolt F.J.E., Dik P.E., GroENENDIJK P., QUERNER E.P., SMIT M.F.R., 2004. SIMGRO 5.0.1. Theory and model implementation. Alterra-Report 913.1. Wageningen, Alterra.

\section{STRESZCZENIE}

\section{Analiza sposobów gospodarki wodnej zmierzających do ograniczenia powodzi na przykładzie zlewni holenderskich}

Słowa kluczowe: dorzecze, ewapotranspiracja, modelowanie, opad, scenariusz, wody gruntowe, wody powierzchniowe, zlewnia

Powodzie w północnej części Holandii stwarzają poważne zagrożenie ekonomiczne dla gęsto zaludnionych obszarów. Dlatego też na obszarze pilotowym podjęto badania, mające na celu ocenę retencji wody jako sposobu ograniczenia powodzi w dwóch zlewniach rzecznych. Warunki hydrologiczne zlewni zobrazowano wykorzystując model SIMGRO w odniesieniu do wód podziemnych i powierzchniowych. Model kalibrowano za pomocą odpływów i poziomów wód gruntowych. 
Następnie zdefiniowano i testowano różne warianty sposobów oceny możliwości retencjonowania wody w zlewni. Pierwszym sposobem była retencja dużych przepływów wody za pomocą przepustów i zastawek w górnej części zlewni. Drugi sposób polegał na wypłycaniu cieków i zwiększeniu pojemności tarasów zalewowych. Ostatnim sposobem było przetrzymywanie wód powodziowych na specjalnie przeznaczonych do tego terenach w dolnej części jednej ze zlewni. Wyniki analizy dowodzą, że zatrzymywanie wody w górnej części zlewni było wykonalne i mogło spowodować znaczące zmniejszenie fali powodziowej.

Reviewers:

Prof. Andrzej Ciepielowski

Dr. Marek Ślesicki 